\title{
Társadalmi felelősség a központi bankok múködésében*
}

\author{
Lentner Csaba - Szegedi Krisztina - Tatay Tibor
}

Tanulmányunkban abból a hipotézisböl indulunk ki, hogy a központi bankok társadalmi felelőssége sajátos, hiszen ezeket kimondottan a közjó javára hozták létre. Társadalmi felelösségük értelmezéséhez elöször a vállalati társadalmi felelösségvállalás (CSR) fogalmát vizsgáljuk a vállalati gyakorlatban. Ezt követően a központi banki müködésre vonatkoztatva kívánjuk a CSR értelmezését átültetni. Értelmezzük a központi bank tevékenységéhez kapcsolódóan a gazdasági, jogi, etikai és jótékonysági felelösségvállalás fogalomkörét. A Magyar Nemzeti Bank, a Fed, és az Európai Központi Bank, valamint Hollandia, Dánia, Spanyolország, Lengyelország és Csehország központi bankjának tevékenységén keresztül kívánunk példákkal rávilágítani, hogy miként is értelmezzük konkrétan a központi banki gyakorlatban a vállalati társadalmi felelősségvállalás egyes összetevőit.

Journal of Economic literature (JEL) kódok: M14, E58 E44, G28

Kulcsszavak: vállalati társadalmi felelősségvállalás, CSR, központi bank, köztudatosság, pénzügyi stabilitás, üzleti etika, központi bank

\section{Bevezetés}

A 2008-as válságot követően a válságkezelés megkövetelte, hogy a központi bankok módosítsanak addigi, a neoliberális közgazdasági nézeteken nyugvó monetáris politikai gondolkodásmódjukon. A körülmények hatására a vezető központi bankok monetáris politikai gyakorlata tartósan megváltozni látszik. Akerlof és Shiller (2011) szerint a válság legrombolóbb hatása az, hogy bizalomhiány alakul ki a gazdaság szereplőiben a jövőt illetően. 2008-ban, a pénzügyi piacok kezdeti befagyása a bankok egymásba vetett bizalmának megingásából következett. A likviditás eltűnése nyomán később a bizalmatlanság tovaterjedt a többi gazdasági szereplőre is. A pénzzel és a jegybankok pénzteremtési folyamataival kapcsolatban megrendült az emberek

* Jelen cikk a szerző nézeteit tartalmazza, és nem feltétlenül tükrözi a Magyar Nemzeti Bank hivatalos álláspontját.

Lentner Csaba a Nemzeti Közszolgálati Egyetem Közpénzügyi Tanszékének tanszékvezetö egyetemi tanára. E-mail: Lentner.Csaba@uni-nke.hu.

Szegedi Krisztina egyetemi docens a Miskolci Egyetem Gazdálkodástani Intézetében.

E-mail:vgtkrisz@uni-miskolc.hu.

Tatay Tibor egyetemi docens a Széchenyi István Egyetem Gazdasági Elemzések Tanszékén. E-mail: tatay@sze.hu.

A kézirat első változata 2016. december 22-én érkezett szerkesztőségünkbe.

DOI: http://doi.org/10.25201/HSZ.16.2.6485 
bizalma. Braun (2016) ezt a folyamatot elemezve felhívta a figyelmet arra, hogy a pénzzel kapcsolatos közvélekedés (folk theory of money) távol van attól, ahogyan a pénz valójában müködik. Ezt érzékelve számos jegybank, így az angol jegybank (Jakab - Kumhof 2015), a holland jegybank (De Nederlandsche Bank 2016) és a Magyar Nemzeti Bank munkatársai (Ábel - Lehman - Tapaszti 2016) írásaikkal az elterjedt tévedéseket tisztázva próbálták eloszlatni a kételyeket a jegybank hitelességének megőrzése érdekében (Braun 2016:1084).

A pénzügyi szektor magatartása nem változott meg alapvetően a válság óta: még mindig a rövid távú profit kerül előtérbe a hosszú távú óvatosság helyett. Vissza kell térni az alapvető kérdéshez, hogy miként szolgálhatja a pénzügyi szektor a társadalom jólétét. Ehhez elengedhetetlen a pénzügyi stabilitás. A bizalom helyreállítása érdekében változó magatartásra és kultúrára, tisztességre, átláthatóságra és az etikai dimenzió megerősítésére, vállalati felelősségvállalásra van szükség, mint a pénzügyi stabilitás alapvető kritériumaira (Lagarde 2014).

Társadalmi elvárás, hogy a pénzügyi intézményrendszer kultúrája átalakuljon. Az átalakuló pénzügyi szervezeti kultúra megváltozását kell segítenie az átalakuló jegybanki gondolkodási keretrendszernek (Shirakawa 2010). A változó gondolkozási keretrendszerben a 2008-at megelőzően jellemző rövid távú célkitǔzéseket felváltják a közép- és hosszú távra fókuszáló célok, egyben a központi bankoknál megfigyelhető az új szerepkörök keresése (Pesuth 2016). Az új szerepkörök adódhatnak a központi bankok jogszabályokban meghatározott feladatainak változásából. A szerepkörök újrafogalmazása lehet önkéntes, a korábbi jogszabályi kereteken belül elöírt feladatkörök súlypontjainak átrendezésével megvalósuló.

Napjainkra úgy túnik, hogy a központi bankok is a 2008-at megelőző monetáris politikai gondolkodásuktól eltérő keretrendszerbe helyezik el feladataik megvalósítását. A pénzügyi stabilitás biztosításának fókuszba kerülése a központi bankok szerepkörét is megváltoztatta. A hagyományos monetáris irányítási feladatok mellett a pénzügyi szektor felügyelésének és szabályozásának feladatára is kiterjed mandátumuk. A válság kitörése óta a tartós pénzügyi stabilitás mint új mandátum mellett a gazdasági növekedés támogatása is nagyobb súlyt kapott. A mandátum kiszélesedése az eszköztár bővülését is szükségessé tette (Ábel et al. 2014). Ugyanakkor kérdésként merül fel, milyen megközelítéseket kell alkalmazniuk a többes mandátum sikeres végrehajtásához. Kérdés az továbbá, hogy a megváltozott szerep és az új elvárások hogyan elégíthetők ki az ezekhez alkalmazkodó hatékony szervezeti magatartással, irányítási kultúrával (Kahn 2016).

A társadalmi hatások nagyobb súllyal való mérlegelése a döntéshozatalban és a feladatok megvalósításában szükségszerű. A vállalati (elsősorban a nagyvállalati) szektorban már korábban megjelent a társadalmi felelősség tudatos felvállalása. A szemléletmód gyökeret vert a bankszektorban is, és bizonyos mértékben a központi bankok szervezeti múködtetésében is. A továbbiakban a CSR-szemlélet és 
gondolkodásmód fogalmát, fejlődését, valamint a központi bankokra történő értelmezését tekintjük át. Korábbi kutatásainkban már vizsgáltuk a kérdéskört (Lentner et al. 2015). Jelen tanulmányunkban a korábbi gondolatainkat kiegészítve, aktualizálva kívánjuk újrafogalmazni.

\section{A vállalati társadalmi felelősség (CSR) koncepciója}

A vállalati társadalmi felelősség (Corporate Social Responsibility) koncepció jelentős térnyerése figyelhető meg az elmúlt évtizedekben, mind az elméletben, mind a vállalati gyakorlatban (Szegedi 2014). A CSR jelenlegi megközelítései messze túlmutatnak a fogalom korai értelmezésén, amikor a menedzserek kapcsán vetődött fel az, hogy nemcsak gazdasági felelősségük van a tulajdonosok felé, hanem társadalmi felelősségük is a társadalom felé (Dodd 1932:1149). A CSR-definíciók számos változatával találkozhatunk, amikből csaknem negyvenet részletesen elemezve Dahlsrud (2008) öt fő dimenziót különböztetett meg:

1. Környezeti dimenzió - kulcsszavak: tisztább környezet, környezetgazdálkodás, az üzleti tevékenység környezeti szempontjai;

2. Társadalmi dimenzió - kulcsszavak: a társadalom jobbá tétele, a társadalmi szempontok integrálása az üzleti tevékenységbe, a vállalat társadalomra és közösségre gyakorolt pozitív és negatív hatása;

3. Gazdasági dimenzió - kulcsszavak: a gazdasági fejlődéshez való hozzájárulás, hosszú távú nyereségesség

4. Stakeholder-dimenzió - kulcsszavak: érintettek kezelése, párbeszéd az érintettekkel, érintettek bevonása;

5. Önkéntességi dimenzió - kulcsszavak: a kötelező jogszabályokon túlmutató, önkéntes tevékenység.

A fenti csoportosításból is jól látható, hogy a CSR-definíciókban megjelennek a fenntartható fejlődés gazdasági, társadalmi, környezeti pillérei, kiegészítve a stakeholder-megközelítéssel és az önkéntességi dimenzióval. A stakeholder-megközelítés tipikusan a vállalati szféra kapcsán jelent meg. Arra a kérdésre, hogy miért kellene figyelnünk az érintettekre, a válasz az etikai kötelesség, ahogy azt a stakeholder-elmélet kapcsán Evan és Freeman (1988) levezette. A CSR-modell és az érintett felfogás összefüggése azért lényeges, mert ez utóbbi nevesíti, hogy mely érintettek felé vállal felelősséget a vállalat, mégpedig a CSR egyik legismertebb és legelfogadottabb definíciója szerint ez gazdasági, jogi, etikai és jótékonysági felelősséget jelent (Carroll 1979:500). A felelősség szempontjából nem az érintettek ereje, hanem a legitimitása a fontos (Carroll 1991). A CSR négy, egymásra épülő felelősségi területét foglalja össze az 1. táblázat. 


\begin{tabular}{|c|c|}
\hline \multicolumn{2}{|c|}{$\begin{array}{l}\text { 1. táblázat } \\
\text { A vállalati társadalmi felelősség részterületei }\end{array}$} \\
\hline Felelősségi terület & A felelősség tartalma \\
\hline Gazdasági felelősség & $\begin{array}{l}\text { Magában foglalja az egy tulajdonrészre jutó jövedelem maximalizálását, a profit } \\
\text { maximalizálását, az erős versenypozíciót, a magas szintű működési hatékony- } \\
\text { ságot, a hosszú távú sikerességet. }\end{array}$ \\
\hline Jogi felelősség & $\begin{array}{l}\text { A vállalatnak gazdasági felelősségét a jogi kereteken belül kell teljesítenie. A tör- } \\
\text { vények, jogszabályok, helyi rendeletek betartását jelenti, valamint azt, hogy } \\
\text { a vállalatot jogszabálykövető polgárként definiálják, ezenkívül a termékei és } \\
\text { szolgáltatásai is megfeleljenek a jogi követelményeknek. }\end{array}$ \\
\hline Etikai felelősség & $\begin{array}{l}\text { Azoknak a normáknak és elvárásoknak a betartását jelentik, amelyek túlmutat- } \\
\text { nak a jogi felelősségen, nincsenek jogszabályba foglalva. Ezek tükrözik a vevők, } \\
\text { munkavállalók, tulajdonosok, közösségek vonatkozásában a tisztességes, igaz- } \\
\text { ságos, az érintettek morális elvárásait védő és tiszteletben tartó viselkedést. }\end{array}$ \\
\hline Jótékonysági felelősség & $\begin{array}{l}\text { A vállalatok jó polgárként hozzájárulnak az emberi jóléthez, az életminőség } \\
\text { emeléséhez, például a múvészet, az oktatás vagy a közösség önkéntes akciókkal } \\
\text { való támogatásával. Ezek diszkrecionális és önkéntes jellegűek. }\end{array}$ \\
\hline
\end{tabular}

A vállalatok múködésével foglalkozó elméleti szakemberek is általában egyetértenek abban, hogy a vállalatnak felelős, etikus módon kell viselkednie, a kérdés, hogy ez a gyakorlatban hogyan valósulhat meg, és hogyan hat a vállalatok gazdasági teljesítményére (Chikán 2003). A vállalati társadalmi felelősségvállalás üzleti megtérülése kapcsán Kurucz, Colbert és Wheeler (2008) rámutatott arra, hogy ez levezethető a költségek és a kockázatok csökkenéséből, a versenyelőnyből, a reputáció és legitimáció növekedéséből, valamint a win-win jellegű helyzetekből származó értékteremtésből. Margolis, Elfenbeien és Walsh (2009) 167 empirikus kutatást elemzett az elmúlt 35 évből, és pozitív kapcsolatot állapított meg a CSR és a pénzügyi eredmény között, a jótékonysági hozzájárulások, a feltárt visszaélések, valamint az átlátható múködés alapján. Carroll és Shabana (2010) javaslata szerint komplexen kell kezelni ezt az összefüggést, és a pozitív kapcsolathoz az érintettek támogatása is szükséges. A CSR a vállalatok etikai kötelessége, függetlenül attól, hogy az gazdaságilag megtérül-e. Ugyanakkor a vállalati érintettek elvárásainak ilyen jellegű növekedése és a felelős vállalatok piaci elismerése egyre inkább a CSR megtérülését eredményezi, ami pozitív irányba mozdítja el a megközelítés gyakorlatba integrálását.

Archie Carroll (2015a), a 2012-ben CSR-életmúdíjat kapott kutató szerint a vállalati polgárság, az üzleti etika, a stakeholder management, a fenntarthatóság és a közös értékteremtés (creating shared value) koncepciók a vállalati társadalmi felelősségvállalás egymással versengő változatai, megpróbálják egyiket a másik részének tekinteni, vagy többen már most szinonimaként használják őket, és ez a tendencia a jövőben felerősödik. A vállalati gyakorlatban vonzó a fenntarthatóság-megközelítés, mivel inkább semleges, és a jövőre vonatkozó pozitív hozzájárulást fejezi ki, míg a vállalati társadalmi felelősség a jelenben is felelősségvállalást sürget, az üzleti 
etika pedig kritikai szemlélete miatt kevésbé kedvelt (Carroll 2015b). Ahogy a fenntartható fejlődés gyökeres szemléletváltást igényel (Kerekes 2009), úgy a vállalati társadalmi felelősség is az üzleti modell változtatását feszegeti.

A gyakorlatban azonban a vállalatok többségénél a CSR kapcsán még mindig jótékonysági programokkal találkozunk, jelentős részüknél célként jelenik meg a müködési hatékonyság növelése, azonban a vállalatok csak kis részénél érzékelhető az üzleti modell valódi átalakításának igénye (Rangan et al. 2015). Az üzleti modell átalakítása felfogásban a vállalati társadalmi felelősségvállalás közelít a társadalmi vállalkozás fogalmához, amely valamilyen társadalmi probléma megoldására törekszik, a gazdasági fenntarthatóság mellett. A fenntartható fejlődés koncepciója felveti azt, hogy minden vállalkozásnak egyben társadalmi vállalkozásnak is kellene lennie, és fordítva is, harmóniát teremtve a gazdasági, környezeti és társadalmi célok között, hozzájárulva ezzel a fenntartható fejlődéshez.

\section{A CSR elemeinek értelmezése a központi bankok vonatkozásában}

A központi bankok társadalmi felelőssége leginkább a legutóbbi válság kapcsán merült fel. Az amerikai központi bank rendkívüli erőfeszítéseket tett a válság kezelésére és a pénzügyi rendszer megmentésére a globális pénzügyi összeomlás elkerülése érdekében. A központi bankok felelőssége nemcsak a közvetlen intézkedésekben, hanem a későbbi szabályozás kapcsán is jelentős (Schoen 2016). A központi bankok társadalmi felelőssége sajátos, hiszen ezeket kimondottan a közjó javára hozták létre. Céljaikat, feladataikat jogszabályban rögzítik. A központi bankok így meghatározott gazdaságpolitikai célok elérését elősegítő intézmények. Feladataik szerint állami hatósági feladatokat is ellátó szervezetek. Ezért ebben a körben a Carroll (1991) által megfogalmazott társadalmi felelősség csak módosított formában értelmezhető.

A CSR konkrét elemei természetesen különböző formákban jelennek meg az egyes központi bankoknál. Az egyes központi bankok szabályozási környezete, mandátuma, hatóköre eltérő. A 2008-as válságot követően voltak ugyan hasonlóan kezelendő problémakörök, mint például a makroprudenciális kockázatok kezelése, de voltak teljesen eltérő módon orvosolható problémák is. Sajátos volt például a magyarországi devizahitelekhez kapcsolódó stabilitási kockázatok kezelése. A továbbiakban ezért a társadalmi felelősségvállalás elemeire, a szemléletmód meghonosodására egyes központi banki gyakorlatok alapján kívánunk rávilágítani.

\subsection{A központi bankok gazdasági felelőssége}

A központi bankok gazdasági felelőssége eltér az üzleti vállalkozásokra érvényes profitmaximalizálástól, de a magas szintű múködési hatékonyság és a hosszú távú sikeresség a jogszabályi kötöttségek figyelembe vételével értelmezhető. A központi bank gazdasági felelőssége sajátos, céljai ugyanis makrogazdasági szintű gazdaságpolitikai célok, a feladatai jogszabályokban rögzített speciális tevékenységek. 
„A Magyar Nemzeti Bank (MNB) esetében ezt a sajátosságot Lentner et al. (2015:28) a törvényi előírásokból kiemelt megállapításokkal alátámasztva így foglalta össze: „Az MNB elsődleges célja az árstabilitás elérése és fenntartása. Az elsődleges céljának veszélyeztetése nélkül támogatja a pénzügyi közvetítőrendszer stabilitásának fenntartását, ellenállóképességének növelését. Támogatja a pénzügyi közvetítőrendszer gazdasági növekedéshez való fenntartható hozzájárulását. A rendelkezésére álló eszközökkel támogatja a kormány gazdaságpolitikáját."

Az MNB törvényben rögzített alapvető feladatai körében meghatározza és megvalósítja a monetáris politikát. Az MNB jogosult Magyarország törvényes fizetőeszközének kibocsájtására. „A magyar gazdaság külső stabilitásának megőrzése érdekében hivatalos deviza- és aranytartalékot képez, és kezeli azt, devizamúveleteket végez, felvigyázza a fizetési és elszámolási, valamint az értékpapír-elszámolási rendszereket" (Lentner et al. 2015:39). Feladatai ellátásához és az EKB részére fennálló adatszolgáltatási kötelezettségének körében „statisztikai információkat gyűjt és hoz nyilvánosságra”. Az MNB „alakítja ki a pénzügyi közvetítőrendszer egészének stabilitására vonatkozó makroprudenciális politikát", amelynek célja a pénzügyi közvetítőrendszer ellenállóképességének növelése, valamint a pénzügyi közvetítőrendszer gazdasági növekedéshez való hozzájárulásának biztosítása. Ennek érdekében „feltárja a pénzügyi közvetítőrendszer egészét fenyegető üzleti és gazdasági kockázatokat, elősegíti a rendszerszintű kockázatok kialakulásának megelőzését, valamint a már kialakult rendszerszintű kockázatok csökkentését vagy megszüntetését, továbbá hitelpiaci zavar esetén a hitelezés ösztönzésével, a túlzott hitelkiáramlás esetén annak visszafogásával járul hozzá a közvetítőrendszer gazdaságfinanszírozó funkciójának kiegyensúlyozott megvalósulásához. Az MNB szanálási hatósági szerepet tölt be. Továbbá ellátja a pénzügyi közvetítőrendszer felügyeletét, és biztosítja annak zavartalan múködését. A pénzügyi szolgáltatásokat igénybe vevők érdekeit védi" a közbizalom növelése céljából (MNB, tv. 2013, Lentner et al. 2015:39).

A központi bank a jogszabályi kötöttségek ellenére nagy mozgástérrel rendelkezik céljai megvalósításában. 2001 és 2013 között az árstabilitási cél kizárólagos kiemelése miatt az MNB egyéb lehetséges gazdaságot támogató céljai háttérbe szorultak. Ez hasonló a vezető jegybankok 1990-es évektől kialakított politikájához. Az MNB 2013-tól újraértelmezte gazdasági szerepvállalását (Matolcsy 2015). A törvényben rögzített alapfeladatának megfelelően $(M N B, t v .2013)$ szerepet vállalt a devizahitelek forintosításában, a vállalati hitelezés ösztönzésében, az állam finanszírozásának elősegítésében. A devizahitelek forintosítása hozzájárult a bankrendszer stabilitásának növeléséhez, szolgálta a háztartások bizonytalan pozíciójának rendezését. A bankok vállalkozásoknak nyújtott hitelezési tevékenységének ösztönzése a növekedési hitel programban, majd a piaci hitel programban öltött alakot. A hitelezés támogatásán keresztül a jegybank a gazdasági növekedés elősegítését tűzte ki célul. A 2014-ben induló önfinanszírozási program célja az állam piacról 
történő olcsóbb forrásszerzésének támogatása volt. A 2002 és 2010 között jelentősen megnövekedett államadósság és az államadósságon belül a magas devizális kitettség sérülékennyé tette Magyarországot. Mindez az adósságfinanszírozást jelentősen megdrágította. Az MNB önfinanszírozási programjával az adósságon belül a devizaadósság súlyának csökkentését, a forintban történő finanszírozás, illetve e finanszírozásban a belföldi szereplők nagyobb szerepvállalásának elérését célozta.

A 2008-as pénzügyi válságot követően a vezető központi bankok feladatkörében, célrendszerében is változások következtek be. A válság azonnali kezelése, majd a következmények enyhítése a kormányoktól is jelentős állami pénzforrás felhasználását igényelte. A pénzügyi intézmények állami pénzekből történő kisegítésének továbbiakban való elkerülése érdekében az árstabilitás fenntartásának célja mellett a pénzügyi stabilitás feladata kapott lényeges hangsúlyt a központi bankok célrendszerében. A pénzügyi stabilitás fenntartásának feladatát a központi bank feladataként újrafogalmazták az Egyesült Államokban, de példaként hozható fel ebben a körben az Európai Központi Bank is (Neményi 2012).

A válság világszerte ráirányította a figyelmet a központi bankok stabilizáló szerepének fontosságára. Az Európai Központi Bank átfogó vizsgálatokba kezdett az európai bankrendszerben. A Fednél jelentős erőforrásokat fordítottak a pénzügyi stabilitás ellenőrzésére, és a makroprudenciális megközelítés fontos kiegészítője lett az egészséges gazdaságot segítő eszköztárnak (Yellen 2014). Az Európai Központi Banknál a rendkívüli likviditási intézkedések kimutathatóan csökkentették a pénzpiaci feszültségeket (Szczerbowicz 2015). A központi banki feladatok kiterjesztését a jogalkotók világszerte megtették, és maguk a központi bankok döntéshozói is átértékelték intézményeik gazdasági szerepvállalását. 2008-at követően a központi bankok nem szokványos eszközöket vettek igénybe a globális növekedés helyreállítása érdekében (Sági 2010).

A pénzügyi válság miatt szükségessé vált innovatív intézkedések az Európai Központi Banknál a „megbízható éberség” kifejezéssel jellemezhetők. A válság a háztartásoknál, a vállalatoknál és pénzügyi intézményeknél a 2008-at megelőző évtizedben felhalmozódott túlzások és egyensúlytalanságok tünete volt, különösen az adósság és a kockázat felhalmozódása, valamint a növekvő tőkeáttétel. A gyors állami intézkedések ezeket enyhítették ugyan, de a válság újabb zavart eredményezett: az államadósság gyors növekedését. A monetáris politikai döntéshozatal standard és nem szokványos eszközei a döntéshozók alapvető meggyőződését és felelősségét tükrözték. A központi bankok feladata a stabilitás biztosítása. Az EKB tanult az elmúlt harminc év gazdasági folyamataiból, miszerint az akcióknak kiszámítható módon kell történniük, az érintettek számára érthető, az árstabilitási céllal konzisztens keretrendszerben. Ugyanakkor meg kell találni az egyensúlyt a kiszámíthatóság és a nem várt körülmények közepette szükséges rugalmasság között. A válság rendkívüli időszakában a központi bankok által alkalmazott nem szokványos eszközök 
természetüknél fogva kevésbé előrejelezhető hatással voltak. A globális környezetet, amiben döntéseket kell hozni, nagyfokú komplexitás és bizonytalanság jellemzi, így a jövőben is szükség lehet a gyors intézkedésekre. Nagyon lényeges, hogy nem a válság kezelésére, hanem annak megelőzésére kell törekedni. Ez sokszor olyan intézkedéseket követel, amelyek nehezebben érthetőek a kívülállók számára. A szokványos és a nem szokványos eszközök alkalmazása a kötelesség és a következmény etikai megközelítését vetik fel. Normál körülmények között jól múködhet a normák betartása, különleges körülmények között azonban ezeket nem mindig lehet betartani, hanem előtérbe kerül a döntés következményeinek mérlegelése, és az ezért történő felelősségvállalás. Mindkét megközelítésnek egyszerre kell jelen lenni a központi bankok múködésében (Trichet 2010).

\section{2. táblázat}

A Fed felügyelet, ellenőrzés és pénzügyi stabilitás érdekében kitúzött céljai

\begin{tabular}{l|l}
\multicolumn{1}{c|}{ Cél } & \multicolumn{1}{c}{ Intézkedés } \\
\hline $\begin{array}{l}\text { A pénzügyi szektor } \\
\text { stabilitásának } \\
\text { megerősítése }\end{array}$ & $\begin{array}{l}\text { Irányelvek, szabályzatok, eszközök és standardok kifejlesztése. Együttmúködés } \\
\text { a gazdasági szereplőkkel a stabilitási kockázatokra vonatkozó interdiszciplináris } \\
\text { megközelítés kidolgozása érdekében. A válság és negatív következményei kiala- } \\
\text { kulásának valószínűségét csökkentő makroprudenciális irányelvek kidolgozása. }\end{array}$ \\
\hline $\begin{array}{l}\text { A pénzügyi piacok és az } \\
\text { iparági gyakorlat és } \\
\text { struktúrák ellenőrzése }\end{array}$ & $\begin{array}{l}\text { A potenciális rendszerkockázatok előrejelzését és kezelését célzó előremutató, } \\
\text { proaktív megközelítés kifejlesztése és megvalósítása. Egyéni intézmények és } \\
\text { infrastruktúrák felügyelete és ellenőrzése, különös tekintettel azokra, amelyek- } \\
\text { nek jelentős befolyásuk van a pénzügyi rendszerre és a makrogazdaságra. Új } \\
\text { felügyeleti program kidolgozása. }\end{array}$ \\
\hline Válságmegelőzés & $\begin{array}{l}\text { Megfelelő válságkezelési eszközök rendelkezésre állásának biztosítása, megfe- } \\
\text { lelő minőségú pénzügyi adatok. } \\
\text { A pénzügyi stabilitási politika monetáris politika megvalósításában betöltött } \\
\text { szerepének elemzése. A különböző makroprudenciális politikák hatékonyságá- } \\
\text { nak és a monetáris politikával való kapcsolatának elemzése. A pénzügyi stabi- } \\
\text { litási kockázatok figyelése, a pénzügyi és a reálszféra közötti kapcsolatok elem- } \\
\text { zése, a rendszerkockázatot potenciálisan érintő irányelv alternatívák értékelése. }\end{array}$ \\
\hline $\begin{array}{l}\text { Pénzügyi tudomángos és nemzetközi kutatások folytatása stressz-tesztek, makroprudenciális } \\
\text { kutatások }\end{array}$ & $\begin{array}{l}\text { szabályozás és eszközök, valamint egyéb pénzügyi stabilitási témákban. Az ered- } \\
\text { mények tudományos folyóiratokban, konferenciákon történő publikálása. }\end{array}$ \\
\hline
\end{tabular}

Forrás: A Fed (2014) alapján szerkesztve.

Az Európai Unióban 2014 végén megkezdte múködését az egységes felügyeleti mechanizmus (SSM). A keret az EKB-t és a résztvevő országok felügyeleti hatóságait tömöríti egy rendszerbe. A létrehozás célja szavatolni az európai bankrendszer biztonságát és szilárdságát, növelni a pénzügyi integrációt és stabilitást, garantálni a felügyeleti munka következetességét (EKB 2015).

Értelmezésünkben a központi bankok nem szokványos eszközök segítségével megvalósított gazdaságélénkítő lépései a gazdasági felelősségvállalás körébe sorolandó akciók. A gazdasági ciklusokkal összefüggő, az inflációs célt szolgáló kamatváltozta- 
tásokon kívül a válságot megelőző, hozzávetőleg két évtizedben a vezető központi jegybankok nem tettek ilyen lépéseket.

Bár a Fed célrendszerében alapítása óta a teljes foglalkoztatás elérése szerepel, amely cél elérését a gazdasági növekedés ösztönzése elősegíti, a cél elérése kevésbé volt hangsúlyos a válságot megelőző húsz év monetáris gyakorlatában. A Fed 2008-ban kezdte a mennyiségi lazítás politikáját (QE), melyet 2015 végéig több szakaszban módosítva folytatott. A mennyiségi és az kiegészítő minőségi lazítás elsősorban a pénzpiacok likviditását javította, de áttételesen, a vállalatfinanszírozás feltételeinek javításán keresztül kedvezően hatott a növekedés élénkítésére is. A Fed a teljes foglalkoztatási célját az előretekintő iránymutatásán (forward guidance) keresztül a monetáris politika munkanélküliségi rátában kifejezett küszöbértékévé is tette (Csortos et al. 2014), így kétség sem férhetett a munkaerőpiac célokon belüli súlyának növekedéséhez. Az EKB a Feddel összehasonlítva késlekedésben volt. A kezdeti lazítás után a szigorítást fontolgatta, és csak 2014 őszétől jelent meg olyan szokványostól eltérő eszközzel, amely, szintén közvetett módon, a gazdasági élénkülést szolgálta. A késlekedés nehezítette a kilábalást a recesszióból, miközben az Európai Unióban egyre nagyobb lett a társadalmi igény arra, hogy a növekedést a monetáris hatóság is támogassa. A 2014 utolsó negyedében elkezdett, majd 2015 elejétől kibővített eszközvásárlási programot a piac szereplői már egyöntetűen gazdasági stimulusként értelmezték (Lentner et al. 2015:40). Az eszközvásárlási program egyben az állampapírpiaci hozamok kilengéseinek csökkentését is segítette. Az EKB 2016-ban vállalati eszközvásárlási programot hozott létre, amelyet legalább 2017 végéig folytatni kíván. A másodlagos piaci eszközvásárlás deklarált célja az inflációs cél elérésének támogatása mellett a háztartások és vállalatok hitelfelvételi feltételeinek javítása is (EKB 2017).

A központi bankok gazdasági felelősségét tehát úgy értelmezhetjük, hogy a központi bankoknak érzékenyebbeknek kell lenniük a válságjelenségek szociális hatásaira. A központi bank gazdasági felelősségi körébe soroljuk a fentieken túl a feladatkörében levő tevékenységek hatékony, korszerű, zavarmentes ellátását. Ilyen tevékenységként értelmezzük példaként a fizetési és elszámolási rendszerek hatékony, a gazdasági szereplők igényeit kielégítő üzemeltetését. A gazdasági felelősségvállalás további elemeként említhetjük a központi bank szervezetének hatékony múködtetését. Ez a szint lényegében azonosan értelmezhető CSR-elem az üzleti vállalkozásoknál megszokottal.

\subsection{A központi bankok jogi felelőssége}

A központi bankok jogi felelőssége is eltér az üzleti vállalkozásokétól. A jegybankok sajátos szerepénél fogva a jogi felelősség kérdése is sokkal árnyaltabb értelmezést kíván. 
A Magyar Nemzeti Bank hatósági feladatkörében ellátja a pénzügyi piacok, valamint a pénzügyi szervezetek felügyeletét. Ebben a szerepkörben jogalkalmazóként is fellép. Az MNB jogszabályi felhatalmazás alapján maga is jogszabályalkotó. Az MNB véleményét ki kell kérni a tevékenységi köréhez, valamint a pénzügyi intézményrendszer múködéséhez kapcsolódó és egyéb, törvényben meghatározott jogszabályok alkotásakor. A jogszabályok betartása mellett tehát a jogi keretek alakítása, értelmezése, a jogszabályok betartatása kapcsolódik a központi bank jogi felelősségvállalásához. Az MNB feladatai 2013-tól bővültek, és a monetáris politika mellett a pénzügyi vállalkozások felügyeleti szerveként is múködik. E feladata arra irányul, hogy ellássa a pénzügyi közvetítőrendszer felügyeletét, biztosítsa a pénzügyi közvetítőrendszer zavartalan, átlátható és hatékony múködését. Elő kell segítenie a pénzügyi közvetítőrendszer részét képező személyek és szervezetek prudens múködését. E feladata kiterjed a tulajdonosok gondos joggyakorlásának ellenőrzésére, a nemkívánatos üzleti és gazdasági kockázatok feltárása. A már kialakult kockázatok csökkentése vagy megszüntetése, illetve az egyes pénzügyi szervezetek prudens múködésének biztosítása érdekében megelőző intézkedéseket alkalmaz. Az MNB védi a pénzügyi szervezetek által nyújtott szolgáltatásokat igénybe vevők érdekeit a pénzügyi közvetítőrendszerrel szembeni közbizalom erősítése céljából. Pénzügyi Békéltető Testületet múködtet a fogyasztó és a pénzügyi szervezetek vagy személyek között létrejött vitás ügyek bíróságon kívüli rendezése érdekében (MNB tv. 2013).

Az MNB komoly szerepet játszott a lakossági devizahitelek forintosításának keretet adó jogszabály megalkotásában is. Kidolgozta a forintosítás megvalósításának szabályait. Ehhez kapcsolódott a bíróságok által a devizahitelek után jogtalanul felszámoltnak talált költségek elszámolási szabályainak kidolgozása.

Az MNB a monetáris politika letéteményeseként befolyásolja a belföldi fizetőeszköz keresletét és kínálatát. Az 1990-es évektől a neoliberális elvek szerint szinte csak az árstabilitást célként maguk elé tűző jegybankok a rendelkezésre álló monetáris politikai eszköztárból csak kevés instrumentumot alkalmaztak. Az MNB a gazdasági felelősség vállalásának megfelelő szélesebb horizontú célkitǔzések megvalósításához az üzleti és alkalmazott eszköztárát is átalakította és bővítette. Kolozsi és Hoffmann (2016) rámutatott arra, hogy a monetáris eszköztár működtetése nem tekinthető csupán technikai feladatnak, hiszen a monetáris politika hatékonyságát az eszköztár határozza meg. Az eszköztár működtetése a bankrendszer számára átalakított szabályrendszert jelent. A törvényi kereteken belül az üzleti és alkalmazott eszköztár újraformálása jogi háttérmunkát igényelt, a jogi felelősségvállalásban is leképeződött.

A jegybankok jogi felelőssége terén végbement változások nemzetközi tendenciáinak áttekintését kezdjük a Fed esetével. A Fed alapvető feladat- és felelősségi körét az 1913-ban elfogadott Federal Reserve Act szabályozza. A 2008-as válságra történő válaszlépések hatására számottevő változások következtek be az amerikai pénzügyi rendszer szabályozásában (Biedermann 2012). Barack Obama (2009) elnök 2009. 
június 17-én tartott beszédében hangsúlyozta, hogy a válság oka a visszaéléseket nem megakadályozó szabályozás, valamint a felelőtlenség kultúrája, és a bizalom helyreállítása érdekében alapvető reformra van szükség. A 2010-ben elfogadott Dodd-Frank Wall Street reform- és fogyasztóvédelmi törvény célja: „az Egyesült Államok pénzügyi stabilitásának elősegítése, a pénzügyi rendszer elszámoltathatóságának és átláthatóságának javítása, a „túl nagy, hogy bukjon” jelenség megszüntetése, az amerikai adófizetők védelme a tőkeinjekciók beszüntetése révén, a fogyasztók védelme a pénzügyi szektorban elburjánzott visszaélésektől..."1. A Fedet érintő egyik alapvető változás, hogy a céljai közé bekerült a pénzügyi stabilitás fenntartása is. Ezenkívül a törvény alapján a Fed nemcsak a bankholding társaságok, hanem a jelentős „nem bank” pénzügyi intézmények felügyeletét is ellátja, valamint kidolgozza és publikálja az ezekkel szemben megnövekedett prudenciális elvárásokra vonatkozó javaslatát. Nem megfelelő felügyeleti szervi intézkedés esetén a Fednek jogában áll intézkedni a „nem bank” pénzügyi intézmények esetén is (Székely 2012). A felügyeleti hatósági funkció fontosságát hangsúlyozza Kecskés és Halász (2013): A válság során gyakran felmerült a felelősök megtalálásának igénye. A politikai helyzetet többször érte az a kritika, hogy a gazdasági lobbi érdekeinek megfelelően túlzottan enyhe szabályokat alkotott. Bár az Egyesült Államokban 2002-ben szigorú reformokat vezettek be, a szigorú szabályok önmagukban nem képesek garantálni a hosszú távon kiszámítható gazdasági működést. Ehhez elengedhetetlen ugyanis a szabályok szigorú és hathatós betartatása.

Lentner, Szegedi és Tatay (2015:41) részletesen ismertették az Európai Központi Bankrendszer alapvető feladatait, melyeket a 2012-ben elfogadott Alapokmány szabályoz (EKB 2012). Az EKB függetlenségét az egységes monetáris politikáról szóló intézményes keretfeltételekben (a Szerződés és az Alapokmány) fektették le. Az EKB-nak joga van kötelező erejű rendeleteket hozni, amennyiben azok a KBER feladatainak ellátásához szükségesek, valamint az EU Tanácsa által hozott jogszabályokban megjelölt egyéb konkrét esetekben. Az EKB a hitelintézetek prudenciális felügyeletére és a pénzügyi rendszer stabilitására vonatkozó uniós jogszabályok hatálya és végrehajtása tárgyában tanácsot adhat a Tanácsnak, a Bizottságnak vagy a tagállamok hatáskörrel rendelkező hatóságainak, illetve ezek az EKB-val konzultálhatnak (EKB 2012).

Az EKB jogi felelősségvállalásának további elemeit a 2014 végén induló egységes felügyeleti mechanizmus keretén belül értelmezhetjük. Az EKB mint független uniós intézmény a bankfelügyelethez kötődő felvigyázói funkcióját az európai érdekek figyelembevételével olyan módon látja el, hogy egységes megközelítést alakít ki a napi szintű felügyeletre vonatkozóan, összehangolt felügyeleti lépéseket és korrekciós intézkedéseket foganatosít, valamint biztosítja a rendeletek és felügyeleti irányelvek következetes alkalmazását. Az EKB a nemzeti felügyeletekkel közösen

\footnotetext{
${ }^{1}$ Lentner et al. (2015:42) így ismerteti a Dodd-Frank Act 2010 rendelkezéseit.
} 
felel az egységes felügyeleti mechanizmus hatékony és következetes múködéséért. Jogkörébe tartozik a felügyeleti felülvizsgálat, helyszíni szemle és egyéb vizsgálat lefolytatása, banki engedélyek kibocsátása és visszavonása. Feladata a bankok befolyásoló részesedésre vonatkozó beszerzési és eladási tevékenységének vizsgálata, az EU prudenciális szabályainak betartatása és magasabb tőkekövetelmény, ún. puffer megállapítása az esetleges pénzügyi kockázatok kivédésére (EKB 2014b).

\subsection{A központi bankok etikai felelőssége}

A központi bankok etikai felelőssége túlmutat a jogszabályi kötelezettségekben rögzített feladatteljesítéseken. Ez a jogszabályokon túlmutató, önként vállalt felelősség az érintettek irányában többféle módon megnyilvánulhat. Általában elmondható, hogy lényeges a központi bank hitelessége, függetlensége és elszámoltathatósága. A központi bankba vetett bizalmat determináló tényezők kapcsán megoszlanak a vélemények. Egy kérdőíves kutatás szerint ez a professzionalizmussal és a függetlenséggel függ össze, nem az átlátható múködéssel (Kril et al. 2016). Ugyanakkor a legújabb, átfogó kutatás kimutatta, hogy a transzparencia kedvezően járul hozzá a bizonytalanság csökkentéséhez (Naszódi et al. 2016).

Az MNB a korábbi hagyományaira építve újrafogalmazta társadalmi felelősségvállalási stratégiáját, amely 2013-tól jelentős változásokon ment keresztül. Ebben hangsúlyozottan helyet kaptak az etikai értékek. Az MNB alapvető értékei a függetlenség, a felelősség és közjóra törekvés. Fontos feladatának tekinti a közbizalom erősítését és a hiteles és transzparens múködést. További etikai felelősségi területként az MNB célként jelölte meg a pénzügyi fogyasztóvédelem erősítését. Ennek keretében fokozott figyelmet fordít a pénzügyi szolgáltatók és az ügyfelek közti kapcsolat jogszerűségére és tisztességes voltára. Mindez támogatja a pénzügyi rendszerbe vetett bizalom megerősítését (MNB 2014).

Az MNB kiadványai a gazdaság szereplőinek tájékoztatását szolgálják. Általuk a központi bank döntései, múködése átláthatóbbakká válik. Emellett a pénzügyi folyamatokban való tájékozottságot is növelik. A spanyol központi banknál kiemelkedő értékként jelenik meg a transzparencia, aminek célja a közcélú információkhoz való hozzájutás támogatása és a közszféra elszámoltathatóságának elősegítése (Banco de España 2017a).

Munkavállalói számára az MNB támogatást nyújt a családalapításhoz, az egészséges életmód kialakításához. Az egyenlő bánásmód megvalósítására meghirdette az "egyenlő munkáért egyenlő bért" alapelvet. Múködése során törekszik a környezettudatosságra (MNB 2014 b). A Dán Nemzeti Banknál ugyancsak hangsúlyos a munkavállalók iránti felelősségvállalás, ügyelnek például a nem, a kor és a rangidősség szerinti sokszínűségre, a munkavállalók oktatására és fejlesztésére, az egészséges munkahelyre, de az utánpótlás érdekében is karrieresteket (Careers Evening) rendez és PhD-ösztöndíjakat nyújt a bank (Danmarks Nationalbank 2017a). 
A Fed értékrendszere a teljesítményértékek mellett etikai értékeket is magában foglal (Fed 2014). Ennek pillérei az elszámoltathatóság, a tisztesség és a független nézőpontok figyelembevétele. Az elszámoltathatóság azt jelenti, hogy a Fed Igazgatósága elszámoltatható, és felelős a közvélemény, az USA kormánya és a pénzügyi közösség felé. A tisztesség kitétele szerint az igazgatóság a tisztesség legmagasabb normáit betartva viselkedik a nyilvánossággal, a pénzügyi közösséggel és munkavállalóival. A független nézőpont az, hogy a rendszer regionális struktúrája támogatja a munkavállalók sokszínűségét, az inputforrások sokféleségét és a független szakmai ítéletet (lásd részletesebben: Lentner et al. 2015:42).

Korábbi írásunkban így ismertettük a Fed egyik tagbankjának, a Chicago Fednek a nyilatkozatát: „a vállalati társadalmi felelősséget szolgáltatási víziójuk természetes kiterjesztésének tekintik. Fontosnak tartják a belső és külső érintettek (iskolák, szakemberek, civilek, helyi közösségi szervezetek) közötti együttműködést, és meggyőződésük, hogy a CSR tevékenység jobb üzleti teljesítményt és erősebb szervezetet eredményez. Banki vezetőkből álló CSR Tanácsot hoztak létre 2011-ben, amelynek feladata a CSR stratégia kidolgozása." (Lentner et al. 2015:42) Bemutattuk azt is, hogy a Fed a CSR keretén belül az etikai felelősségvállalás körében kiemelte a munkavállalói sokszínűség, a beszállítói sokszínűség, a közösségfejlesztés és a szakpolitikai tanulmányok készítése, a környezetvédelem fontosságát. Munkavállalói sokszínűség elve alapján támogatják a sokszínú, a munkatársak bevonásán alapuló munkakörnyezetet, amelyben tisztelik, fair módon kezelik a munkavállalókat és egyenlő esélyeket biztosítanak számukra. A 2010-ben elfogadott Dodd-Frank Wall Street Reform and Consumer Protection Act hatályba lépése után külön kisebbségi és női szervezetet hoztak létre. A beszállítói sokszínűség elve szerint elkötelezettek a beszállítói sokszínúség mellett, ami magában foglalja a kisebbségek és a nők által tulajdonolt vállalkozások bevonását. A pénzügyi szolgáltatásokhoz való fair hozzáférés tanulmányozásával és támogatásával, a közösségfejlesztéssel és szakpolitikai tanulmányok készítésével a gazdasági növekedési célok elérését segítik. A környezetvédelem nézőpontja a napi tevékenységbe integrál számos olyan üzleti gyakorlatot, melyek célja a tisztább és egészségesebb környezet (Lentner et al. 2015).

Az Európai Központi Bank missziójának megfogalmazásában számos etikai elem kapott helyet. Ilyen például, hogy az EKB céljainak megvalósítása során kiemelkedő jelentőséget tulajdonít a hitelességnek, a bizalomnak, az átláthatóságnak és az elszámoltathatóságnak (EKB 2014a). Az EKB világosan megfogalmazza feladatait és azok végrehajtásának módját. Rendszeresen tájékoztatja a nyilvánosságot a gazdasági helyzetre vonatkozó értékeléséről, és arról, hogy mit tud elérni a monetáris politika, és mi esik hatókörén kívül.

A függetlenség elve alapján az árstabilitás elősegítése érdekében sem az EKB, sem a nemzeti központi bankok, sem pedig a döntéshozó szerveik tagjai nem kérhetnek vagy fogadhatnak el utasítást uniós intézménytől és szervtől, az uniós tagállamok 
kormányaitól, sem bármely más testülettől. Az EKB átlátható módon, időben biztosítja a nyilvánosság és a piacok számára a stratégiájával, értékeléseivel és politikai határozataival, valamint eljárásaival kapcsolatos minden lényeges információt. Nagyon lényeges a nyilvános monetáris politika, és a nyilvánossággal folytatott hatékony kommunikáció. Közzéteszi monetáris politikai stratégiáját és tájékoztatást ad a gazdasági folyamatokra vonatkozó rendszeres értékeléséről. Ezáltal a piacok jobban ki tudják számítani a monetáris politikai lépéseket, aminek köszönhetően hatékonyabban és pontosabban alakítják várakozásaikat, így felgyorsulhat a szükséges gazdasági alkalmazkodás, és javulhat a monetáris politika hatékonysága. Az EKB a demokratikus alapelvnek megfelelően közfeladatokkal felruházott független intézményként felelősséggel és elszámolással tartozik az állampolgárok és azok választott képviselői irányában. Az EKB felelősségvállalását mutatja, hogy rendszeres beszámolói keretében túllép a jogszabályban megszabott kötelezettségein. A kötelező, negyedéves beszámoló helyett havonta tesz közzé beszámolót, továbbá a Kormányzótanács tagjai beszédekben tájékoztatják a nyilvánosságot az aktuális témákról. Az elnök és alelnök rendszeres sajtótájékoztatót tart.

Az EKB magatartási kódexben szabályozza a Kormányzótanács tagjai részéről elvárt viselkedést, különös tekintettel a függetlenségre, az összeférhetetlenségre és a titoktartásra. Kérdéses esetben etikai tanácsadóhoz fordulhatnak a tagok (EKB 2002). Az EKB személyzetére vonatkozó etikai keretrendszer a titoktartásra, az erőforrások használatára, a munkahelyi viselkedésre, azaz a zaklatás, megfélemlítés tilalmára, az összeférhetetlenségre, az ajándékok elfogadására, a magánjellegú tevékenységekre, a beszerzésre, a díjakra, kitüntetésekre, a külső személyekkel való kapcsolatra, valamint a bennfentes kereskedelemre fogalmaz meg előírásokat. A munkatársak segítséget kérhetnek az etikai biztostól, és neki jelenthetik is a visszaéléseket (EKB 2011).

Más jegybankok gyakorlatát sorra véve a vállalati társadalmi felelősségvállalás komplex felfogása és szervezeten belüli intézményesítettsége tekintetében kiemelkedő a Holland Nemzeti Bank. Missziójuknak a „Working on trust” integrált részét képezi a fenntarthatóság, és nagy hangsúlyt fektetnek arra, hogy a CSR megjelenjen a bank kulcsfontosságú kötelezettségei között. Vállalati társadalmi felelősségvállalásuk részét képezi a tisztességes és a szabályoknak megfelelő működés (integrity and compliance), a környezettudatosság és a fenntartható beszerzés, a széles értelemben vett sokszínúség - ami kiterjed a nemre, a kulturális háttérre, a korra, a szexuális irányultságra, a fizikai korlátoltságra, a vallási meggyőződésre és a képzettségre is -, valamint a társadalom különböző szféráiban való szerepvállalás. A bank széleskörü dialógust folytat érintettjeivel, és a transzparencia növelése érdekében 2010-től CSR-riportot készít, a vállalati CSR-területen már széles körben alkalmazott és egyre inkább a közszféra területén is terjedő Global Reporting Initiative irányelvei alapján. (De Nederlansche Bank 2017). 


\subsection{A központi bankok filantropikus felelőssége}

Korábbi írásunkban (Lentner - Szegedi - Tatay 2015) külön fejezetben foglalkoztunk a központi bankok filantropikus (jótékonysági) felelősségének kérdésével. Azokat az önként vállalt akciókat értjük ez alatt, amelyek hozzájárulnak a társadalmi fejlődéshez.

A gazdasági válság elhúzódása a gazdaság szereplőinek pénzügyi kultúrában levő hiányosságaira hívta fel a figyelmet. A pénzügyi ismeretek magasabb szintje, a pénzügyi kultúra mélyítése elősegíti a pénzügyi stabilitást (Kovács 2015), s ugyanakkor a magasabb pénzügyi kultúra egyéni szempontból is védelmet nyújt. A kultúra viselkedést befolyásoló szerepe etikai értékeket is hordoz. Ezért fontos szerepet kap a tájékoztatás, a pénzügyi kultúra emelése az oktatáson keresztül. A Magyar Nemzeti Bank nagy hangsúlyt fektet a pénzügyi szolgáltatásokat igénybe vevők tájékozottságának növelésére, az információs aszimmetria csökkentésére (Csiszárik - Szigeti 2015). „A Magyar Nemzeti Bank céljának tekinti a pénzügyi oktatás, kutatás és a tudomány támogatását, nemcsak hazai, de nemzetközi szinten is. Ez többek között magában foglalja magas szakmai színvonalú cikkek, kiadványok nemzetközi publikálását, konferenciaszervezést hazai és nemzetközi szakemberek részvételével. Fontosnak tartja az értékmegőrző, értékközvetítő és értékteremtő szerepvállalást, a szakmai jellegű támogatások nyújtását, a hátrányos helyzetű csoportok segítését, az esélyegyenlőség javítását. Karitatív adományozást folytat és részt vesz a nemzeti kulturális javak megvásárlásában (MNB 2014 b)."

A Fed elősegíti a pénzügyi kultúra fejlesztését célzó különböző kutatások, publikációk, konferenciák szervezését és lebonyolítását. A szűken vett pénzügyi kutatásokon és konferenciákon kívül megjelennek a tágabb, gazdasági és társadalmi vonatkozású kutatások és konferenciák is, például fiatal munkavállalói kutatás, az amerikai háztartások jólétének kutatása, gazdasági mobilitási konferencia (Board of Governors of the Fed 2014). Ezen túlmenően a Fed tagbankjai aktív közösségi tevékenységet végeznek. A Fed Munkavállalói Akció Csoport missziója, hogy jó polgárként felelősséget vállaljanak azokért a közösségekért, amelyekben dolgoznak és élnek, segítsék mások életét és erősítsék a közösséget. Tevékenységük olyan változatos programokra is kiterjed, mint az önkéntes házfestés, a családok számára történő játékgyűjtés, kismamák számára kisbabaruha-gyűjtés, ételfőzés hajléktalanszállók részére (Fed of Minneapolis 2014). E tevékenységek sorába tartozik a középiskolák mentorálása, általános iskolások olvasásának, matematikai ismeretszerzésének segítése, véradás, adománygyüjtés AIDS, rák- és cukorbetegek részére (Fed of New York 2014)².

Az Európai Központi Bank a pénzügyi kultúra fejlesztése érdekében ismeretterjesztő anyagokat, videókat, játékokat jelentet meg a honlapján, amellyel elsősorban a fiatalabb korosztályt és tanáraikat célozza meg (EKB 2014b). Ezen kívül számos pub-

\footnotetext{
${ }^{2}$ Lásd erről Lentner - Szegedi - Tatay 2015:44.
} 
likáció jelenik meg az EBK honlapján. A pénzügyi kultúra fejlesztése hangsúlyosan jelenik meg számos európai ország központi bankjánál is. A Lengyel Nemzeti Bank például támogatja a kutatást, valamint konferenciákat, szemináriumokat rendez a központi bankok gazdasági életben betöltött szerepéről, ezen belül többek között a monetáris politika, pénzügyi stabilitás, a központi banki kompetenciák kérdésköréről (Narodowy Bank Polski 2017). A fogyasztóvédelem kérdésköréhez kapcsolódóan a pénzügyi ismeretek fejlesztését segíti elő a Cseh Nemzeti Bank is kézikönyvek, munkafüzetek tanárok és diákok közötti terjesztésével, szemináriumok rendezésével, interaktív kiállításokkal (Czech National Bank 2017). A Dán Nemzeti Bank a Danish Journal of Economics tudományos folyóirattal, PhD-ösztöndíjakkal, női közgazdászokat jutalmazó díjjal segíti a gazdasági kultúrát (Danmarks Nationalbank 2017b). A gazdasági kutatás, az oktatás és egyetemi hallgatók támogatása ugyancsak célja a Spanyol Nemzeti Banknak is, és megjelenik a humanitárius és társadalmi munka, valamint nonprofit centrumok létrehozása is (Banco de España 2017b). A holland központi bank a társadalom részének tekinti magát, ami megjelenik a közösségi munkában, a szponzorációban, a támogatásokban, a kulturális, oktatási és jóléti szféra támogatásában is (De Nederlansche Bank 2017).

\section{4. Összegzés}

A válságkezelés során a központi bankok társadalmi felelősségvállalása hangsúlyosabbá vált. Társadalmi elvárás lett, hogy a központi bankok az árstabilitás fenntartása mellett további célokat is maguk elé tűzzenek. Mandátumukat kibővítették, a pénzügyi stabilitás megőrzése ugyanolyan elérendő célként jelenik meg számukra napjainkra, akár az inflációs cél megvalósítása. A stabilitási cél elérése érdekében a központi bankok jelentősen módosították az alkalmazott eszköztárukat. A deklarált célok, a célrendszer módosulása miatt a központi bankok piacszabályozási gyakorlatában bekövetkező változásokat a társadalmi felelősségvállalás keretrendszerében elsősorban a gazdasági és a jogi felelősségvállalás körében azonosítottuk.

A társadalmi felelősségvállalás keretrendszerében az etikai dimenzió a jogi kereteken túlnyúlva szolgálja a központi bankok hatékonyabb, a kor elvárásainak jobban megfelelő múködését. A jótékonysági dimenzió a hatékonyabb kommunikációt segíti, erősíti a társadalom pénzügyi kultúráját, ezáltal növeli a pénzügyi stabilitást.

A központi bankoknak jelentős szerepük lehet a bankrendszerbe és a gazdaságba vetett bizalom fenntartásában, amit elősegíthet a központi bankok sajátosságaihoz igazodó társadalmi felelősségvállalási szemlélet. A CSR vállalati modelljében alkalmazott gazdasági, jogi, etikai és jótékonysági elvárások megfelelő adaptálással értelmezhetők a központi bankokra is. A központi bankok társadalmi felelőssége sajátos, hiszen e bankokat kimondottan a közjó javára hozták létre, meghatározott gazdaságpolitikai célok elérését elősegítő, állami hatósági feladatokat is ellátó szer- 
vezetek. A gazdasági válság hatására nyilvánvaló, hogy a központi bankok társadalmi felelössége nőtt. Érzékenynek kell lenniük a gazdasági folyamatok társadalmi hatásaira, szerepet kell vállalniuk abban, hogy a pénzügyi szektor egyes szereplőinek felelőtlensége ne okozhasson jelentős közpénzfelhasználást, reálgazdasági visszaesést, valamint társadalmi feszültséget.

\section{Felhasznált irodalom}

Ábel István - Csortos Orsolya - Lehmann Kristóf - Madarász Annamária - Szalai Zoltán (2014): Az inflációs célkövetés megújulása a válság után. Hitelintézeti Szemle. November: $35-56$.

Ábel István - Lehmann Kristóf - Tapaszti Attila (2016): A pénz és a bankok ellentmondásos kezelése a makroökonómiában. Hitelintézeti Szemle. 15(2): 33-58.

Akerlof, G. - Schiller, R. (2011): Animal spirits. Corvina, Budapest.

Banco de España (2017b): Transparency. http://www.bde.es/bde/en/secciones/ sobreelbanco/Transparencia/ Letöltés ideje: 2017. március 01.

Banco de España (2017b): Cultural and social work. http://www.bde.es/bde/en/secciones/ sobreelbanco/Transparencia/Informacion_econ/Atenciones_benef/Atenciones_ cult_21239a5c48b0a41.html Letöltés ideje: 2017. március 01.

Biedermann Zsuzsánna (2012): Az amerikai pénzügyi szabályozás története. Pénzügyi Szemle 3: 337-354.

Board of Governors of the Fed (2014): Community Development. http://www.Federalreserve. gov/communitydev/default.htm Letöltés ideje: 2014. december 13.

Braun, B. (2016): Speaking to the people? Money, trust, and central bank legitimacy in the age of quantitative easing. Review of International Political Economy, Volume 23: 1064-1092. https://doi.org/10.1080/09692290.2016.1252415.

Carroll, A. B. (1979): A Three-Dimensional Model of Corporate Performance. Academy of Management Review, 4( 4): 497-505. https://doi.org/10.2307/257850.

Carroll, A. B. (1991): The Pyramid of Corporate Social Responsibility: Toward the Moral Management of Organizational Stakeholders. Business Horizons, July-August.

Carroll, A. B. (2015a): The State of CSR in 2015 and Beyond. In: Global Compact (2015): Global Compact International Yearbook 2015. Macondo Publishing GmbH: 10-13.

Carroll, A. B. (2015b): Corporate social responsibility: The centerpiece of competing and complementary frameworks. Organizational Dynamics, 44: 87-96. https://doi. org/10.1016/j.orgdyn.2015.02.002. 
Carroll, A. B. - Shabana, K. M. (2010): The business case for corporate social responsibility: A review of concepts, research and practice. International Journal of Management Reviews, 12(1): 85-105.

Chikán, A. (2003): Vállalatgazdaságtan. Aula Kiadó, Budapest.

Csiszárik-Kocsir Ágnes - Szigeti Cecília (2015): Financial culture of youth in Hungary. In: Radek Kratochvíl, Jiři Vopava, Vladimír Douda (szerk.): Proceedings of the 4th MAC 2015. Prague, Csehország, 2015.02.20-2015.02.21. Prague. MAC Prague consulting.

Csortos Orsolya - Lehmann Kristóf - Szalai Zoltán (2014): Az elöretekintő iránymutatás elméleti megfontolásai és gyakorlati tapasztalatai. MNB-Szemle, 2014. július, 45-55. o.

Czech National Bank (2017): Consumer protection. http://www.cnb.cz/en/consumer/index. html Letöltés ideje: 2017. március 01.

Dalhsrud, A. (2008): How corporate social responsibility is defined: an analysis of 37 definitions. Corporate Social Responsibility and Environmental Management. 15(1): 1-13. https://doi.org/10.1002/csr.132.

Danmarks Nationalbank (2017a): Careers at Danmarks Nationalbank. http://www. nationalbanken.dk/en/career/Pages/Default.aspx Letöltés ideje: 2017. március 01.

Danmarks Nationalbank (2017b): Danmarks Nationalbank and economic research. http:// www.nationalbanken.dk/en/about_danmarks_nationalbank/DN_and_economic_research/ Pages/default.aspx Letöltés ideje: 2017. március 01.

De Nederlandsche Bank (2017): Corporate Social Responsibility. https://www.dnb.nl/en/ about-dnb/organisation/maatschappelijk-verantwoord-ondernemen/index.jsp Letöltés ideje: 2017. március 01.

De Nederlandsche Bank. (2016): Central Banks Keep Finger on Money Creation Pulse. DBBulletin 19 August; accessed at www.dnb.nl/en/news/news-and-archive/ dnbulletin-2015/dnb325255.jsp, 3 September 2016.

Dodd, E. M. Jr. (1932): For Whom are Corporate Managers Trustees? Harvard Law Review 45(7): 1145-1163. https://doi.org/10.2307/1331697.

Dodd-Frank Act (2010): https://www.sec.gov/about/laws/wallstreetreform-cpa.pdf Letöltés ideje: 2014. december 14.

EKB (2002): A Kormányzótanács Tagjai számára szóló magatartási kódex https://www.ecb. europa.eu/ecb/legal/pdf/hu_mou_on_code_of_conduct_consolidated_f.pdf Letöltés ideje: 2014. december 14. 
EKB (2011): Az EKB személyzete alkalmazási feltételeinek az etikai keretrendszert tartalmazó része. https://www.ecb.europa.eu/ecb/legal/pdf/c_04020110209hu00130017.pdf Letöltés ideje: 2014. december 14.

EKB (2012): Jegyzőkönyv a Központi Bankok Európai Rendszere és az Európai Központi Bank Alapokmányáról. Az Európai Unió hivatalos lapja, 2012. 10. 26. https://www.ecb.europa. eu/ecb/legal/pdf/c_32620121026hu_protocol_4.pdf Letöltés ideje: 2014. december 14.

EKB (2014a): Az Európai Központi Bank küldetése. https://www.ecb.europa.eu/ecb/orga/ escb/ecb-mission/html/index.hu.html Letöltés ideje: 2014. november 12.

EKB (2014b): Ismeretterjesztő anyagok. https://www.ecb.europa.eu/ecb/educational/html/ index.hu.html Letöltés ideje: 2014. december 14.

EKB (2015): Egységes Felügyeleti Mechanizmus. https://www.bankingsupervision.europa. eu/about/thessm/html/index.hu.html Letöltés ideje: 2015. január 05.

EKB (2017): Az Európai Központi Bank 2017/103 határozata

https://www.ecb.europa.eu/ecb/legal/pdf/celex_32017d0004_hu_txt.pdf Letöltés ideje: 2017. február 20.

Evan, W. M. - Freeman, R. E. (1996): A modern vállalat stakeholder-elmélete: kantiánus kapitalizmus. In: Boda Zs. - Radácsi L. (1996). Vállalati etika. BKE Vezetőképző Intézet, Budapest: 93-108.

Federal Reserve Bank (2014): Annual Performance Plan. http://www.Federalreserve.gov/ publications/gpra/files/2014-gpra-performance-plan.pdf Letöltés ideje: 2014. december 10.

Federal Reserve Bank of Chicago (2016): Corporate Social Responsibility. https://www. chicagoFed.org/utilities/about-us/csr/index Letöltés ideje: 2016. december 10.

Federal Reserve Bank of Minneapolis (2014): Community Involvement. https://www. minneapolisfed.org/about/careers/community-involvement Letöltés ideje: 2014. december 14.

Federal Reserve Bank of New York (2014): Community Involvement. http://www.newyorkFed. org/careers/comminvolve.html. Letöltés ideje: 2014. december 14.

Jakab, Z. - Kumhof, M. (2015): Banks are not intermediaries of loanable funds - and why it matters. Bank of England Working Paper, No. 529. https://doi.org/10.2139/ssrn.2612050.

Kahn, A. (2016): Central Bank Governance and the Role of Nonfinancial Risk Management. IMF Working Paper. February 2016. https://doi.org/10.5089/9781498376051.001. 
Kecskés András - Halász Vendel (2013): Stock Corporations: A Guide to Initial Public Offerings, Corporate Governance and Hostile Takeovers. HVG-ORAC - LexisNexis, Budapest-Bécs, 191 o.

Kerekes Sándor (2009): A környezetgazdaságtan alapjai. Aula Kiadó.

Kolozsi Pál Péter - Hoffmann Mihály (2016): A külső sérülékenység csökkentése monetáris politikai eszközökkel. Pénzügyi Szemle 2016/1: 9-34.

Kril, Z. - Leiser, D. - Spivak, A. (2016): What Determines the Credibility of the Central Bank of Israel in the Public Eye? The International Journal of Central Banking, March 2016. http:// www.ijcb.org/journal/ijcb16q1a3.pdf Letöltés ideje: 2016. december 10.

Kovács Levente (2015): A pénzügyi kultúra kutatása és aktuális feladataink. Gazdaság és Pénzügy, 2. évfolyam: 79-88.

Kurucz, E. - Colbert, B. - Wheeler, D. (2008): The business case for corporate social responsibility. In: A. Crane, A. McWilliams, D. Matten, J. Moon, \& D. Siegel (eds.): The Oxford handbook of corporate social responsibility. Oxford University Press: 83-112.

Lagarde, C. (2014): Economic Inclusion and Financial Integrity-an Address to the Conference on Inclusive Capitalism. https://www.imf.org/external/np/speeches/2014/052714.htm Letöltés ideje: 2014. december 07.

Lentner Csaba - Szegedi Krisztina - Tatay Tibor (2015): A központi bankok társadalmi felelőssége. Vezetéstudomány 46(9-10): 35-47.

Margolis, J. D. - Elfenbein, H. A. - Walsh, J. P. (2009): Does it Pay to Be Good...And Does it Matter? A Meta-Analysis of the Relationship between Corporate Social and Financial Performance. (March 1). http://dx.doi.org/10.2139/ssrn.1866371.

Matolcsy György (2015): Egyensúly és növekedés. KAIROSZ Könyvkiadó, Budapest, 644 o.

MNB (2014): Függetlenség és Felelősség. A Magyar Nemzeti Bank Alapokmánya, május. https://www.mnb.hu/letoltes/a-magyar-nemzeti-bank-alapokmanya-1.pdf. Letöltés ideje: 2014. december 13.

MNB (2014): A Magyar Nemzeti Bank társadalmi felelősségvállalási stratégiája https://www.mnb.hu/letoltes/mnb-tarsadalmi-spread-low-1.pdf Letöltés ideje: 2016. december 11.

MNB tv. (2013): Magyar Nemzeti Bankról szóló törvény (2013). https://www.mnb.hu/ajegybank/kozerdeku-adatok/tevekenysegre-mukodesre-vonatkozo-adatok/a-szervalaptevekenysege-feladata-es-hataskore/jegybanktorveny Letöltés ideje: 2014. december 14. 
Naszódi Anna - Csávás Csaba - Erhart Szilárd - Felcser Dániel (2016): Which Aspects of Central Bank Transparency Matter? A Comprehensive Analysis of the Effect of Transparency of Survey Forecasts. The International Journal of Central Banking, December 2016. http:// www.ijcb.org/journal/ijcb16q4a4.pdf Letöltés ideje: 2016. december 11.

Neményi Judit (2012): A pénzügyi válság hatása központi bankok szabályozására. Verseny és szabályozás. MTA KRTK Közgazdaság-tudományi Intézet. Május:167-219. Narodowy Bank Polski (2017): Research \& Conferences. http://www.nbp.pl/homen.aspx?f=/badania/ konferencje_en.htm Letöltés ideje: 2017. március 01.

Obama, B. (2009): Remarks by the President on 21st Century Financial Regulatory Reform. The White House Office of the Press Secretary, June 17, 2009.

Pesuth Tamás (2016): A jegybanki szerepkör újradefiniálása. Pénzügyi Szemle 2016/1: 35-49. o.

Rangan, V. K., Chase, L. \& Karim, S. (2015): The Truth About CSR. Harvard Business Review, January-February: 40-49.

Sági Judit (2010): Discretionality of Monetary Policy. In: Radványi Tamás (szerk.): Pénz és társadalom: Dolgozatok a BGF Pénzügyi és Számviteli Kara tudományos mühelyéböl. Budapest: Budapesti Gazdasági Főiskola Pénzügyi és Számviteli Főiskolai Kar: 59-62.

Shirakawa M. (2010): Revisiting the philosophy behind central bank policy. Speech by Mr Masaaki Shirakawa, Governor of the Bank of Japan, at the Economic Club of New York, New York, 22 April. http://www.bis.org/review/r100427b.pdf Letöltés ideje: 2016. december 10.

Schoen, E. J. (2016): The 2007-2009 Financial Crisis: An Erosion of Ethics: A Case Study. Journal of Business Ethics, February.

Smith, A.: The Theory of Moral Sentiments. 1759. http://www.ibiblio.org/ml/libri/s/SmithA_ MoralSentiments_p.pdf Letöltés ideje: 2012. április 11.

Sunstein R. C. - Thaler R. H. (2011): Nudge. Jobb döntések egészségröl, pénzröl és boldogságról - a pénzügyi válság után. Budapest, Manager Könyvkiadó és Könyvkereskedő $\mathrm{Kft}, 264 \mathrm{o}$.

Szczerbowicz U. (2015): The ECB Unconventional Monetary Policies: Have They Lowered Market Borrowing Costs for Banks and Governments? The International Journal of Central Banking, December 2015. http://www.ijcb.org/journal/ijcb15q5a3.pdf. Letöltés ideje: 2016. december 11.

Szegedi Krisztina (2014): Possibilities of Corporate Social Responsibility. In: Berényi L. (Ed.) (2014): Management Challenges in the 21st Century. LAP LAMBERT Academic Publishing. 
Székely Anita (2012): A válságra tett szabályozói válaszlépések az Egyesült Államokban. Hitelintézeti Szemle, 3: 230-253. http://www.bankszovetseg.hu/wp-content/ uploads/2012/10/230-253-szekely1.pdf Letöltés ideje: 2012. december 13.

Trichet, J. C. (2010): Central banking in uncertain times: conviction and responsibility. Speech by Jean-Claude Trichet, President of the ECB, at the symposium on "Macroeconomic challenges: the decade ahead", Jackson Hole, Wyoming, 27 August 2010. http://www.ecb. europa.eu/press/key/date/2010/html/sp100827.en.html Letöltés ideje: 2014. december 10.

Yellen, J. L. (2014): Remarks at the Panel Discussion on "Shaping the Future of the Macroeconomic Policy Mix" At the "Central Banking: The Way Forward?", International Symposium of the Banque de France, Paris, France, November 7. http://www. Federalreserve.gov/newsevents/speech/yellen20141107a.htm Letöltés ideje: 2014. december 07. 